IJBPAS, March, Special Issue, 2022, 11(3): 587-593

ISSN: $2277-4998$

International Journal of Biology, Pharmacy

and Allied Seiences (IJBPAS)

'A Bridge Betuben Caboratory and QReador'

WwW.ijbpas.com

\title{
A CRITICAL REVIEW ON THE ANTIHELMINTHIC ACTIVITY OF AN UNEXPLORED POLYHERBAL FORMULATION: KETAKI SARKARA FROM AROGYA RAKSHA KALPADRUMAH
}

\section{SWAMI I ${ }^{1}$, VISWAROOPAN $D^{2 *}$, SWAPNIL $\mathrm{CR}^{3}$ AND PANI $\mathrm{S}^{4}$}

1: Post Graduate Scholar, Department of Kaumarbhritya, Parul Institute of Ayurved, Parul University, Limda, Vadodara- 391760

2, 3: Associate Professor, Department of Kaumarbhritya, Parul Institute of Ayurved, Parul University, Limda, Vadodara- 391760

4: Professor\& HOD, Department of Kaumarbhritya, Parul Institute of Ayurved, Parul University, Limda, Vadodara - 391760

*Corresponding Author: Dr. Viswaroopan D: E Mail: deepthi.viswaroopan@paruluniversity.ac.in Received 12 ${ }^{\text {th }}$ Dec. 2021; Revised $14^{\text {th }}$ Jan. 2022; Accepted $7^{\text {th }}$ Feb. 2022; Available online $5^{\text {th }}$ March 2022

https://doi.org/10.31032/IJBPAS/2022/11.3.1073

\section{ABSTRACT}

Background: Being the oldest methodical branch of knowledge, Ayurveda speaks its reality in the sketch of philosophy. There are many classical formulations which are commonly practiced for treating various diseases but in maximum cases there is lack of data regarding their detailed mechanism of action. Such one multidrug classical formulation is Ketaki Sarkara ${ }^{i}$ mainly practiced in Kerala. It is an unexplored formulation mentioned in Arogya Raksha Kalpadrumah (Kerala's Tradition of Ayurvedic Pediatric Care) Text in Krimi Chikitsa (Treatment of Worm Infestation) chapter. The ingredients are Ketaki (root) [Pandanus tectorius Soland], Vilanga [Embelia ribes Burm.F.], Vyosha [Zingiber officinale Roxb.], Bhunimba Andrographis paniculata (Roxb.) Wall. Ex Nees, Palasa (flower) [Butea monosperma (Lam.) Kuntze, Syn.B.], Abhaya [Terminalia chebula Retz.] and Guda (Jaggery). 
Material: Material related to Ketaki Sarkara is collected by online articles, journals, ayurvedic text books.

Conclusion: In this review different properties of Ketaki Sarkara is being focused and its widely use in present day general practice is suggested for the purpose of dose uniformity, palatability and applicability.

\section{Keywords: Ketaki Sarkara, Ayurveda, Arogya Raksha Kalpadrumah, Krimi roga}

\section{INTRODUCTION}

Krimi roga (Worm Infestation) is found in all age groups, but they are much more of a problem in children who are just beginning to learn to cope with their parasitic enemies. Prevalence in some areas appears very high while it is less elsewhere in the country. More than $50 \%$ prevalence for $T$. trichiura was reported from two different locations from the states of Assam and Andhra Pradesh and more than 50\% prevalence for hookworm was reported from a single location from the state of Andhra Pradesh. The states of Uttarakhand, Uttar Pradesh, Jharkhand, Manipur, Maharashtra and Puducherry reported a prevalence higher than 20\%. Less than $20 \%$ prevalence was reported from another seven states of Delhi, Himachal Pradesh, Chandigarh, Madhya Pradesh, Rajasthan, Gujarat and Karnataka. ${ }^{\text {ii }}$ Being considered as the most important phase of life, childhood determines the wellbeing, learning and behavior across the lifespan of an individual. Many authors have mentioned the important concepts of
Kaumarbhritya (Pediatric). One can find the lighthouse to ayurvedic pediatric concepts on exploring the Kaikkulangara Rama Warrier written treasure of Kerala's splendid tradition of Ayurveda, Arogya Raksha Kalpadrumah (original name Arogya kalpadrumah) (Kerala's Tradition of Ayurvedic Pediatric Care) Text. Many new diseases and formulations are mentioned in this book one of which is "Ketaki Sarkara", an unexplored formulation mentioned in Krimiroga Chikitsa (Treatment of Worm Infestation) chapter.

\section{CONCEPT OF KRIMI}

The term "Krimi" is derived from the word Kramu, which means to step, to roam, or to walk. It has come out from "Kramu Padavikshepe", means which move with the legs are termed as Krimis.

In Ayurveda's classical literature called Samhita detailed descriptions of Krimi are available.

a) Charaka Samhita - In 19th chapter of Sutra Sthana "Ashtodariya Adhyaya" total 20 numbers of Krimi 
were mentioned where they are classified into Bahya krimi like Yuka \& Pipilika and Abhyantara Krimi as Purishaja, Kaphaja, Shonitaja and Malaja. It is also mentioned that this classification is for those other than the Sahaja Krimi which are usually found in humans in plenty.

Later in 7th chapter of Vimana sthana, "Vyadhitarupiya Vimana" after describing the difficulty in determining serious or mild disease in patients, Krimiroga is described in detail with respect to its management.

b) Sushruta Samhita - In Uttartantra under title of "Krimiroga pratisedha" Number of Krimi, Nidan, Rupa, classification and treatment were described. Detail descriptions of "Gandupada Krimis" have been mentioned in Purishaja type of Krimi.

c) Kashyapa Samhita - Only the treatment portion of Krimi roga is found in the Chikitsa sthan "Krimi chikitsita”. Administration of bitter and pungent drugs in Krimi roga are well explained in this chapter. Medicated bath for the external Krimi in Dwivraniya adhyaya and only the total number of krimi in Sutra sthan chapter is mentioned.

d) Harita Samhita - Acharya Harita has described nomenclature, number, classification, etiology, symptomatology, pathogenesis and treatment in the 5th chapter clearly. Questions related with survival of Krimi in Kostha and their answers were unique to the author. Krimis like 7 types of external Krimis and 6 types of internal Krimis are classified.

Purisha accumulation is the main cause for internal type of Krimi, infesting which more like snake in the Kaphakoshtha is explained here. Krimis name according to their shape, size and habitat. For example Pruthumunda, Sukshma, Anavaha and Suchimukha etc. etiology, pathogenesis, symptomatology and treatment of these Krimis are explained in a nice way in the $3 \mathrm{rd}$ Sthana 5th chapter.

e) Bhela Samhita - In the available Bhela Samhita only the number of Krimi i.e. 20 and their names are mentioned.

\subsection{NUMBER OF KRIMI}




\begin{tabular}{|c|c|c|}
\hline S. No. & Texts & Number \\
\hline 1. & Charaka Samhita & $\mathbf{2 0}$ \\
\hline 2. & Sushruta Samhita & $\mathbf{2 0}$ \\
\hline 3. & Ashtanga Sangraha & $\mathbf{2 0}$ \\
\hline 4. & Harita Samhita & $\mathbf{2 0}$ \\
\hline 5. & Bhela Samhita & $\mathbf{2 0}$ \\
\hline 6. & Madhava Nidanam & $\mathbf{2 2}$ \\
\hline 8. & Sharangadhara Samhita & $\mathbf{2 0}$ \\
\hline
\end{tabular}

\subsection{TREATMENT OF KRIMI ${ }^{\mathrm{iii}}$}

As per Ayurved principle there are three basic methods for the treatment of Krimi:-

a) $\boldsymbol{A P A K A R S A N A}$ - Scratching of dosha, mala and krimisanghata forcefully. Different types of apkarsana methods are:-

(i) Vamana (Therapeutic Emesis)

(ii) Virechana (Therapeutic Purgation)

(iii) Shirovirechana (Nasal Therapy)

(iv) Asthapana Basti (Medicated enema)

2. PRAKRITI VIGHATA - Destruction of the producing environment.

3. NIDANA PARIVARJANA- Elimination the causative factor which promote the germinating and growing of the Krimi. It emphasizes on importance of Ahara, Vihara and life style as same as treatment.

3. KETAKI SARKARA ${ }^{\mathrm{iv}}$
This drug is mentioned in the $10^{\text {th }}$ chapter of Arogya Raksha Kalpadrumah (original name Arogya kalpadrumah) - (Kerala's Tradition of Ayurvedic Pediatric Care) Text written by Kaikkulangara Rama Warrier.

बालकेतकी मूलस्य पलान्यम्भसि षोडश। पक्त्वा द्रोणेत्र पादस्थे पूते वस्त्रावगालनात् ।।

सितापलाष्टकं दत्वा विपक्के सान्द्रतांगते। विलडग़ा व्योष भूनिंब पलाशकुसुमाभयाः।। कर्षाशध्चूर्णिताक्षिप्त्वा संयोज्याथावतारयेत्। प्राग्विरेचनमाधाय पश्चादेतां प्रयोज्येत् । ।

मस्तुना सह सयुंक्तां मधुना वा रसेन वा। धात्रीफलानां मुस्ताया यदा केतकी शर्रकाम्। (Arogya Raksha Kalpadrumah. Ch-10/Pg-65)

\subsection{INGREDIENTS OF KETAKI} SARKARA

\begin{tabular}{|c|c|c|}
\hline S. No. & INGREDIENTS & MATRA \\
\hline 1 & Ketaki (root) & 1 Part \\
\hline 2 & Vilanga & $1 / 4$ Part \\
\hline 3 & Vyosha & $1 / 4$ Part \\
\hline 4 & Bhunimba & $1 / 4$ Part \\
\hline 5 & Palasa (flower) & $1 / 4$ Part \\
\hline 7 & Abhaya & 8 Part \\
\hline
\end{tabular}




\subsection{METHOD OF PREPARATION}

One pala (48 gm) of Ketaki root is added with the sixteen pala (768 gm) of water, is boiled and reduced to one forth of the total amount and filtered well. Eight pala (384 gm) of jaggery is added to it and boiled till the mixture attains the consistency to prepare lehya. The drugs vilanga, vyosha, bhunimba, palasa flower and abhaya are taken in the amount of one karsha (12 gm) separately and powdered is added to the above mixture and stirred well.

ANUPANA - Honey, Mastu, Juices of Dhatri, Musta.

$>$ Prior to administer this drug to a patient proper purgation should be done.

\section{DISCUSSION}

\section{ANALYSIS OF ACTION}

\subsection{AYURVEDIC PROPERTIES OF}

\section{DRUGS $^{\mathbf{v}}$}

\begin{tabular}{|c|c|c|c|c|c|c|}
\hline $\begin{array}{l}\text { Sr. } \\
\text { No. }\end{array}$ & NAME & BOTANICAL NAME & $\begin{array}{l}\text { RASA } \\
\text { (Taste) }\end{array}$ & $\begin{array}{c}\text { GUNA } \\
\text { (Quality) }\end{array}$ & $\begin{array}{c}\text { VIRYA } \\
\text { (Potency) }\end{array}$ & $\begin{array}{c}\text { VIPAKA } \\
\text { (Assimilation) }\end{array}$ \\
\hline 1 & Ketaki & $\begin{array}{c}\text { Pandanus tectorius } \\
\text { Soland }\end{array}$ & $\begin{array}{c}\text { Bitter, Sweet, } \\
\text { Pungent }\end{array}$ & Light & Hot & Pungent \\
\hline 2 & Vilanga & $\begin{array}{c}\text { Embelia ribes } \\
\text { Burm.F. }\end{array}$ & $\begin{array}{c}\text { Pungent, } \\
\text { Astringent }\end{array}$ & Light, Dry & Hot & Pungent \\
\hline 3 & Vyosha & $\begin{array}{c}\text { Zingiber officinale } \\
\text { Roxb. }\end{array}$ & Pungent & $\begin{array}{c}\text { Light, } \\
\text { Unctuous }\end{array}$ & Hot & Sweet \\
\hline 4 & Bhunimba $^{v i}$ & $\begin{array}{c}\text { Andrographis } \\
\text { paniculata(Roxb) } \\
\text { Wall. Ex Nees }\end{array}$ & Bitter & Light, Dry & Hot & Pungent \\
\hline 5 & Palasa & $\begin{array}{c}\text { Butea monosperma } \\
\text { (Lam.) Kuntze, Syn.B. }\end{array}$ & $\begin{array}{c}\text { Pungent, Bitter, } \\
\text { Astringent, } \\
\text { Sweet }\end{array}$ & $\begin{array}{l}\text { Light, Dry, } \\
\text { Movable }\end{array}$ & Cold & Sweet \\
\hline 6 & Abhaya & $\begin{array}{c}\text { Terminalia chebula } \\
\text { Retz. }\end{array}$ & $\begin{array}{c}\text { Astringent, } \\
\text { Sour, Sweet, } \\
\text { Bitter, Pungent }\end{array}$ & Light, Dry & Hot & Sweet \\
\hline 7 & $\begin{array}{c}\text { Jaggery } \\
\text { (Guda) }\end{array}$ & \multicolumn{5}{|c|}{$\begin{array}{c}\text { Madhuram (sweet), Sakshram, Katuteekshnam (pungent-bitter), Snigham (unctuous), Saram } \\
\text { (mobility),Ushnam (hot), Natiseetam (not so cold), Madhurapaka (sweet assimilation), Pittaghnam, } \\
\text { Vataghnam, Natipittaghnam, Kaphakaram, Vatapittakaram, Mootrala sodhanam (urinary cleaner) } \\
\text {, Balaam (promotes strength), Vrusyam (aphrodisiac), Ruchyam ( appetizer), Brimhanam } \\
\text { (nourishes), Raktha sodhanam ( blood cleaner) }\end{array}$} \\
\hline
\end{tabular}

Due to ingredient's rasapanchak (properties) (Pungent, Bitter rasa and Usna virya) environment in which Krimi (worms) develops is destructed resulting in the destruction and inhibition of the growth of Krimi (worms).

\section{Pharmacological Activity}

- KETAKI - Performs anthelminthic properties due to its ethyl acetate and ethanol extracts. $^{\text {vii }}$

- VILANGA - Water and alcoholic extracts are anthelmintic against earthworms and decreased the motility leading to mortality. Embelin 
salts are anthelmintic. Di - isobutyl amino derivatives of embelin showed anthelmintic activity. Alcoholic extract was effective in 80 $\%$ infestation by A.lumbricoid. ${ }^{\text {viii }}$

- VYOSHA - Anthelmintic activity of alcoholic extracts of rhizomes of $\mathrm{Z}$. officinale against human Ascaris lumbricoldes is reported. Lethal effect of Z. officinale on Anisakis larvae in vitro was also found. ${ }^{\text {ix }}$

- BHUNIMBA - The water extract of dried leaves of bhunimba was found to be active against adult worms of Brugia malayi in vitro and the aqueous and methanol extracts for in vitro has anthelmintic activity against adult earth worms Pheretima posthuma. $^{\mathrm{x}}$

- PALASA - Effect of aqueous extracts of $B$. monosperma (Lam.) Kuntze is seen on the mature live $H$. contortus from sheep and goats. ${ }^{\mathrm{xi}}$

- ABHAYA - Anthelmintic Activity of Alcoholic and Aqueous Extract of Fruits of Terminalia chebula Retz was reported. ${ }^{\text {xii }}$

- JAGGERY- Elettaria cardamomum (L.) enriched jiggery exhibited anthelminthic properties against earthworm was found. ${ }^{\text {xii }}$

\section{CONCLUSION}

The review literature of Ketaki Sarkara shows that all the ingredients due to their rasapanchak (properties) (Bitter, Pungent taste and Hot potency) performs prakriti vighata of Krimi (worm). Pharmacological studies have demonstrated the antihelminthic activity from Ethanol Extracts of Ketaki [Pandanus tectorius Soland], Vyosha [Zingiber officinale Roxb.] and Abhaya [Terminalia chebula Retz.] and aqueous extract of Vilanga [Embelia ribes Burm.F.], Bhunimba Andrographis paniculata(Roxb.) Wall. Ex Nees ,Palasa [Butea monosperma (Lam.) Kuntze, Syn.B.] and Abhaya [Terminalia chebula Retz.].

Jaggery with Elettaria cardamomum (L.) also shows anthelminthic properties.

\section{CONSENT}

Not applicable

\section{ETHICAL APPROVAL}

Not applicable

\section{COMPETING INTERESTS}

Authors have declared that no competing interests exist.

\section{REFERENCES}

i Dr. Lal Krishnan. Krimi roga chikitsa. Arogya Raksha Kalpadrumah. Varanasi: Chowkhamba Sanskrit Series Office; Edition $2^{\text {nd }} 2012$.p. 65. 
ii Salam, N., Azam, S. Prevalence and distribution of soil-transmitted helminth infections in India. BMC Public Health 17, 201 (2017).

https://doi.org/10.1186/s12889-017-4113-2

iii Charaka Samhita Vimana Sthana; Vyadhitrirupiya Adhyaya: Chapter 7 verse 14, Charaka Samhita, Vidyotini hindi commentary by Kashinath Shastri \& Gorakhnath Chaturvedi, Part-I, Published by Chaukhambha Bharati Academy, Varanasi, India, reprint year; 2009.

iv Dr. Lal Krishnan. Krimi roga chikitsa. Arogya Raksha Kalpadrumah. Varanasi: Chowkhamba Sanskrit Series Office; Edition $2^{\text {nd }} 2012$.p. 65.

$\checkmark$ (The Ayurvedic Pharamacopoeia of India, n.d.)

${ }^{v i}$ Kumar, Praveen \& Naik, Raghavendra \& Nishteswar, K. \& Panara, Kalpesh \& Joshi, Krutika. (2013). Experimental and Clinical Evidence of Andrographis paniculata (Roxb.) Wall. Ex Nees (Bhunimba) -A Review. IJPBA. 4. 1086-1093.

vii Adkar, Dr. Prafulla. (2014). Review Article Pandanus odoratissimus(Kewda): A Review on Ethnopharmacology, Phytochemistry, and Nutritional Aspects. Advances in Pharmacological Sciences. Volume 2014. 19. 10.1155/2014/120895. viii Singhal, Tina \& Kumar, Ajay. (2019). Vidanga-An Ayurvedic Contraceptive.

${ }^{\text {ix }}$ Iqbal, Zafar \& NADEEM, QAZI \& Khan, M.N. \& Akhtar, Muhammad \& WARAICH, FAISAL. (2000). In Vitro Anthelmintic Activity of Allium sativum, Zingiber officinale, Curcurbita mexicana and Ficus religiosa. Int J Agr Biol. 3.

x Hossain, Md \& Urbi, Zannat \& Sule, Abubakar \& Rahman, K.M.. (2014). Andrographis paniculata (Burm. f.) Wall. ex Nees: A Review of Ethnobotany, Phytochemistry, and Pharmacology. The Scientific World Journal. 2014. 28. $10.1155 / 2014 / 274905$.

xi Singh, Gagandeep \& Singh, Rajeev \& Verma, Pawan \& Singh, R. \& Anand, A.. (2013). Anthelmintic efficacy of aqueous extract of Butea monosperma (Lam.) Kuntze against Haemonchus contortus of sheep and goats. Journal of Parasitic Diseases. 39. 10.1007/s12639-013-0324-3.

xii Dwivedi, Dr. Sumeet. (2008). Anthelmintic Activity of Alcoholic and Aqueous Extract of Fruits of Terminalia chebula Retz.. Ethnobotanical Leaflets.

xiii Ravish, Mushfique \& Ahmad, Wasim \& Zeenat, Fahmeeda \& Mustafa, Suboohi. (2020). An Appraisal of Medicinal Properties of Jaggery: A Review. 12. 75-80. 